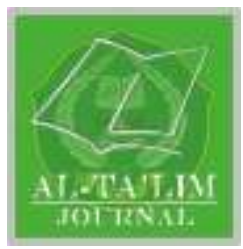

AL-TA'LIM JOURNAL, 24 (2), 2017, (165-173)

(Print ISSN 1410-7546 Online ISSN 2355-7893)

Available online at http://journal.tarbiyahiainib.ac.id/index.php/attalim

\title{
High Touch Approach and Its Relationship with Students' Learning Outcomes at IAIN Bukittinggi
}

Received: 06 ${ }^{\text {th }}$ July 2017; Revised: 13 ${ }^{\text {th }}$ July 2017; Accepted: $17^{\text {th }}$ July 2017

Permalink/DOI: http://dx.doi.org/10.15548/jt.v24i2.281

\section{Darul Ilmi}

Institut Agama Islam Negeri Bukittinggi, Indonesia.

E-mail: ilmid10@yahoo.com

\begin{abstract}
Learning without students' center tends to create less passionate students in following the lecture. They tend to ignore their lecturer. They have less attention, and try to create ineffective conditions, therefore, the learning atmosphere will become less effective to achieve the intended goals. The purpose of the research is to determine the process of learning, the implementation of High Touch approach, and factors that influence its implementation. Classroom action research approach was used at department of mathematics which involve students who enroll at academic year 2016/2017 IAIN Bukittinggi. The research was done in two cycles in which one cycle conducted three meetings. The instruments used were observation, essay questions, and tasks given to students. The results show that there is an improvement in students' participation and activeness in learning when their lecturer builds learning experience through reinforcement, affection, guide, directive action, and good modeling by student-center andselflearning activities, and independent learning skill orientations showed in cycle I and II. It implies that implementing high touch may lead students to be more active, creative, and fun in learning.
\end{abstract}

Keywords: High touch, student-centered and learning outcomes

How to Cite: Ilmi, D. (2017). High touch approach and its relationship with students' learning outcomes at IAIN Bukittinggi. Al-Ta Lim Journal, 24 (2). doi:http://dx.doi.org/10.15548/jt.v24i2.281

\section{INTRODUCTION}

Education is a strategic investment to improve rivalry among countries in politics, laws, cultures, technologies, and defenses all over the world. In accordance to this condition, the developed countries simultaneously improve their education focusing on human capital and human investment. This is the reason to improve the capability to compete among nations by having high quality resources. Educational investment is human resources used to develop human potentials in which includes both benefit and social returns (Collins \& Clark, 2003; Davidsson \& Honig, 2003; Weinberger, 1998).

The quality of education output is affected by learning quality (Moore \& Kearsley, 2011; Nightingale \& O’Neil, 2012; Sims, Dobbs, \& Hand, 2002). The quality is determined by prerequisite conditions of 
students' mastery, learning skills, facilities, and physical and socio-emotional environment. Thus, learning process as operationalization of educational practice done by lecturer should contain high-tech and high-touch. The hightouch (the term used "authority") is "educational tool" used by educator to touch students' selves in educational relationship which directs to high-touch condition, in the meaning that educator's treatment positively, constructively, and comprehensively touch students' humanity aspects (Anderson, 2004; Gainor, Goins, \& Miller, 2004; Kulchitsky, 2008; Noddings, 2013).

High-touch implementation or authority used to develop students' personals includes acknowledgment, affection, reinforcement, guidance, directive actions, and modeling. On the other hand, high-tech (education) is "educational tool" used by educator for realization of learning goals achievement directed to the use of high quality technology. It includes curriculum, learning methods, learning equipment, learning environment, and learning assessment. Learning process is done not only by using appropriate materials and methods, but also in line with students' affective and social developments to achieve purposed goals. High tech and authority should be in harmony to improve the learning process and outcome.

The study done by Loughran (2013) showed that the application of authority and educational in learning process was not done well as expected as many problems emerged in relation with mastering difficulty, low of learning skill, insufficient facilities, students' selfhood and physical and socio-emotional environment. Accordingly, efforts to enable learning process improve through implementing authority and education in learning process (Black, Harrison, Lee, Marshall, \& Wiliam, 2004; Gould, 2009; Hord, 2009; Vescio, Ross, \& Adams, 2008).

Kriz (2003) stated that in order to create effective learning environment, the classroom atmosphere should be built by lecturer's authority through engaging students in learning processes. Light, Calkins, \& Cox (2009) furthermore, said that education phenomenon occurs when it grows and develops through authority actualization reflected in the way lecturer teaches in the classroom. Through this process, the lecturer can assure the development of learning situation.

Based on the preliminary survey in the learning process of Mathematics education students in even semester in academic year 2015/2016 at IAIN Bukittinggi, the researcher found that the lecturer tended to show bad attitudes such as talkative, anger, and unfair, while they prefer good, friendly, smart, and kind attitudes. The results also show incompatible relation between lecturer and students because the lecturer tended to make the students inferior and passive. Moreover, students were less passionate to learn, reluctant to participate in discussion, and used to compare between one lecturer and another, thus, efficient learning environment is difficult to achieve.

Regarding to the phenomena above, an analysis of learning process especially the implementation of authority and its relationship with learning outcomes is needed. The research was done towards Mathematics education department students in even semester in academic year 2016/2017 at IAIN Bukittinggi. The lecturer is expected to implement authority and education in learning process based on educational science principles which are related to the learning outcomes. Accordingly, the problems are identified as follow:

1. The lecturer's implementation of authority (high touch) in learning process

2. Learning activities tended to be passive

3. Learning outcomes

4. The relationship between authority and learning outcomes

5. Students' problems include less passionate, less motivated, and passive. 


\section{METHOD}

This research is classified into Action Research in which describes facts, conditions of learning process, or phenomena systematically, factually, and actually Arikunto, (2002); Gay \& Airasian (2000) stated that descriptive research is a research done to collect the information about a phenomenon as it is. The analysis used was descriptive analysis. According to Best (1982) descriptive analysis is an analysis done to know the relationship between independent and dependent variables. The independent variable in this research was high touch, while dependent variable was learning outcomes.

This research describes the improvement of learning process through high touch approach in Islamic education science subject and its relationship with learning outcomes of Mathematics education department students in even semester in academic year 2016/2017 at IAIN Bukittinggi in which the data are quantitative data.

\section{Setting of the Research}

The research was done at IAIN Bukittinggi toward Mathematics education department students in second semester in academic year 2016/2017. The samples were 35 students consisting of 8 males and 27 females.

\section{Students' Environment}

The students were coming from many different backgrounds including educational, socio-economic, and cultural backgrounds gathering in Islamic education science course class.

\section{Time of Research}

The research was done in four months, one semester, in which the Islamic education science course was presented in even semester in academic year 2016/2017.

\section{Indicators of Success}

The indicators of success are presented as follow:

$$
\begin{array}{rll}
90-100 & =\text { Very good } \\
80-89 & =\text { Good } \\
65-79 & =\text { Adequate } \\
55-64 & =\text { Quite Good } \\
0-54 & =\text { Not Good }
\end{array}
$$
students:

The learning process is success when

1. Solve the problems well

2. Ask many questions

3. Share their ideas

4. Done the task well

5. Present the result of task well

6. Pay attention, listen to, and give opinion to their peers' work

7. Participate in giving opinion

\section{General Description of the Research (Action Cycle)}

The steps in this research is named cycle in which one cycle consisted of three meetings. The researcher observed the planning, implementation, observation, and reflection activities. The reflection in the first cycle was used to take further action in the next cycle.

\section{Technique of Data Collection}

To collect the data, the researcher used both direct observation and observation sheet in each cycle. The observation was done to observe the class atmosphere, learning process, students' activities, and the results were written in observation sheet. Tests were also used at the beginning and the end of meeting. Test is a series of questions used to measure students' competence. The tests were 
in essay forms in which the answer is in the form of discussion, reasoning, and exploring ideas (Arikunto, 2002).

\section{Instrument of the Research}

The instruments used in the research:

1. Students' activities sheet containing questions and structured tasks based on the sub-chapters of Educational Bases course. The structured tasks were given both in group and individual.

2. Observation sheet was used to measure students' activities during the learning process. The activities to be observed included

3. The students who asked questions both from lecturer or peers

4. The students who shared their ideas

5. The students who discussed with their peers

6. Understanding and mapping the materials

7. Presenting the results in group

8. Paying attention to peers' presentation

9. Participating in every discussion

\section{Procedure of the Research}

The research was done in two cycles in which each cycle consisted of three meetings, the steps in each cycle:

1. Planning

2. Prepare learning equipment such as syllabus and SAP

3. Prepare the task to be done, questions to be answered, and observation sheet

4. Action

The actions done by students were studying, understanding, and analyzing the materials based on the syllabus, and presenting group works through discussion. In this step, the approach was focused on students' center learning in order to improve learning process quality and gain better outcomes. Thus, the learning scenario was constructed in the form of SAP.

\section{RESULT AND DISCUSSION}

The research was done in Mathematics Education Department in even semester in academic year 2016/2017 IAIN Bukittinggi in which the focus is on improving the students' role in learning. The research, in general included students' activities in learning and learning outcomes.

\section{Cycle I}

In the first meeting, the writer allowed the students to study and analyze the materials by using books, accessing internet and map and identify the material to be explained, the steps of learning process:

1. The students sat in group and were allowed to learn the materials to be presented in discussion in the classroom.

2. The lecturer controlled the discussion; the group presenting was commented by three other groups. Later general comments were allowed to be given by all students.

3. The lecturer observed the discussion, the students who actively participated in giving comment.

4. The lecturer and students concluded the materials discussed.

5. The lecturer re-asked the conclusion made in order to check the students' understanding.

6. The lecturer delivered the next materials and resources to be used.

In the second meeting, the class discussed educational bases materials in which the procedure was quiet the same as the first meeting. The students were asked to bring visual aids in the form of carton related to the materials, then, it is presented by groups, the steps as follow:

1. The students sat in group and were allowed to learn the materials to be presented in discussion in the classroom. 
2. The lecturer controlled the discussion; the group presenting was commented by three other groups. Later general comments were allowed to be given by all students.

3. The lecturer observed the discussion, the students who actively participated in giving comment.

4. The lecturer and students concluded the materials discussed.

5. The lecturer re-asked the conclusion made in order to check the students' understanding.

6. The lecturer delivered the next materials and resources to be used

In the third meeting, the class discussed educational bases materials in which the procedure was quiet the same as the first meeting. The students were asked to bring visual aids in the form of carton related to the materials, then, it is presented by groups, the steps as follow:

The students sat in group and were allowed to learn the materials to be presented in discussion in the classroom.
1. The lecturer controlled the discussion; the group presenting was commented by three other groups. Later general comments were allowed to be given by all students.

2. The lecturer observed the discussion, the students who actively participated in giving comment.

3. The lecturer and students concluded the materials discussed.

4. The lecturer re-asked the conclusion made in order to check the students' understanding.

5. The lecturer delivered the next materials and resources to be used

6. At the end of the third meeting, the lecturer re-asked the materials learned from the first until the third meetings and the students were asked to collect them.

7. Observation

The observation of learning activities was done during learning process. The observer completed the observation sheet and the data collected was analyzed descriptively to show students' activities as described in the table below:

Table 3

\begin{tabular}{|c|c|c|c|c|c|}
\hline No & Learning Activities & $\begin{array}{c}\text { First } \\
\text { Meeting }\end{array}$ & $\begin{array}{c}\text { Second } \\
\text { Meeting }\end{array}$ & $\begin{array}{c}\text { Third } \\
\text { Meeting }\end{array}$ & Average \\
\hline 1 & The students completed the task given & 60 & 70 & 80 & 70 \\
\hline 2 & The students shared their opinion & 30 & 35 & 40 & 35 \\
\hline 3. & The students discussed each other & 40 & 50 & 60 & 50 \\
\hline 4. & The students presented their works & 20 & 30 & 40 & 30 \\
\hline 5 & $\begin{array}{l}\text { The students paid attention to their friends' } \\
\text { presentation }\end{array}$ & 50 & 60 & 70 & 60 \\
\hline 6 & The students who did not participate & 80 & 60 & 50 & 65 \\
\hline 7 & The students who did not care & 50 & 60 & 70 & 60 \\
\hline 8 & The students who were not discipline & 30 & 20 & 20 & 25 \\
\hline 9 & $\begin{array}{l}\text { The students who were chatting during } \\
\text { learning }\end{array}$ & 10 & 15 & 10 & 12,5 \\
\hline
\end{tabular}

The data above shows that there is an improvement from the first until the third meetings in preparing the task given by the lecturer by average was $70 \%$, giving opinion was $35 \%$, discussing with other students was $50 \%$, presenting the works was $30 \%$, paying attention to others' presentation was $60 \%$, not participating was $65 \%$, not caring was $60 \%$, not discipline was $25 \%$, there was an improvement, chatting during learning was 12,5 $\%$, there was an improvement.

In general, there were improvements in cycle I including doing tasks, giving opinion, the way of discussion, and the way of presenting the works, but there were still many 
students did not participate during learning such as not caring and not discipline as much as $60 \%$.

In specific, various strategies implemented during educational bases course affected students' ways in learning process. These results were gotten through implementing high touch approach including affection, mildness, guidance, reinforcement, directive actions, good modeling, and student center development oriented to students' activities.

The results of cycle I describe that there was an improvement in the students' learning process although the results were not satisfying. Only some students were active and wanted to present their works. These phenomena might be caused by great number of groups and lack of preparation.

\section{Cycle II}

Accordingly, the writer minimized the number of groups in cycle II in which four or five students per group. Each student was given the materials' summary and each group mapped the concept in simple visual aid to be presented, the steps are described as follow:

In the first meeting, the writer allowed the students to study and analyze the materials by using books, accessing internet and map and identify educational bases to be explained, the steps of learning process:

1. The students sat in group and were allowed to learn the materials to be presented in discussion in the classroom.

2. The lecturer controlled the discussion, the group presenting was commented by three other groups. Later general comments were allowed to be given by all students.

3. The lecturer observed the discussion, the students who actively participated in giving comment.

4. The lecturer and students concluded the materials discussed.
5. The lecturer re-asked the conclusion made in order to check the students' understanding.

6. The lecturer delivered the next materials and resources to be used.

In the second meeting, the class discussed educational bases materials in which the procedure was quiet the same as the first meeting. The students were asked to bring visual aids in the form of carton related to the materials, then, they were presented by groups, the steps as follow:

1. The students sat in group and were allowed to learn the materials to be presented in discussion in the classroom.

2. The lecturer controlled the discussion; the group presenting was commented by three other groups. Later general comments were allowed to be given by all students.

3. The lecturer observed the discussion, the students who actively participated in giving comment.

4. The lecturer and students concluded the materials discussed.

5. The lecturer re-asked the conclusion made in order to check the students' understanding.

6. The lecturer delivered the next materials and resources to be used

In the third meeting:

1. The students sat in group and were allowed to learn the materials to be presented in discussion in the classroom.

2. The lecturer controlled the discussion; the group presenting was commented by three other groups. Later general comments were allowed to be given by all students.

3. The lecturer observed the discussion, the students who actively participated in giving comment.

4. The lecturer and students concluded the materials discussed. 
5. The lecturer re-asked the conclusion made in order to check the students' understanding.

6. The lecturer delivered the next materials and resources to be used
At the end of the third meeting, the lecturer re-asked the materials learned from the first until the third meetings and the students were asked to collect them.

Table 4. The results of the observation in cycle II are described in the table below:

\begin{tabular}{llllll}
\hline No & \multicolumn{1}{c}{ Learning Activities } & $\begin{array}{c}\text { First } \\
\text { Meeting }\end{array}$ & $\begin{array}{c}\text { Second } \\
\text { Meeting }\end{array}$ & $\begin{array}{c}\text { Third } \\
\text { Meeting }\end{array}$ & Average \\
\hline 1 & The students completed the task given & 70 & 80 & 90 & 80 \\
2 & The students shared their opinion & 40 & 45 & 50 & 45 \\
3. & The students discussed each other & 50 & 65 & 80 & 70 \\
4. & The students presented their works & 30 & 40 & 50 & 40 \\
5 & The students paid attention to their friends' presentation & 60 & 70 & 85 & 72,5 \\
6 & The students who did not participate & 60 & 40 & 40 & 45 \\
7 & The students who did not care & 60 & 70 & 80 & 70 \\
8 & The students who were not discipline & 20 & 15 & 15 & 17,5 \\
9 & The students who were chatting during learning & 10 & 15 & 10 & 12,5 \\
\hline
\end{tabular}

1. In the first, second, and third meeting there was an improvement in preparing tasks although only some group members did the task. This phenomenon happened because the students are used to the way of learning in senior high school.

2. In the results of the first, second, and third meetings there was an improvement in giving opinion as much as $10 \%$ inasmuch as the lecturer stimulated and respected the students' opinion.

3. In presenting their works, still the same students in cycle I presented the materials in cycle II. The materials were presented well because they were directed by course book provided by the lecturer, but there were lack of reasoning and concrete examples.

4. In participating in discussion, still the students who were active in cycle I dominated the discussion, but some students who did not participate in cycle I were able to give their opinion in cycle II.

5. In the first, second, and third meeting, the students respected their classmates who presented the materials because the lecturer directed and gave them the reward.
6. The results of the first, second, and third meetings show that less than $50 \%$ students still not participating in discussion even some other never participate from cycle I until cycle II.

7. In the first, second, and third meeting there was an improvement in not caring, less motivated due to the students' social and cultural background.

8. In cycle II, there were still some students came late to the class and take much time when the lecturer allowed them to go out of the class.

9. There still some students chatted during the learning process, but later they were able to follow the process.

In general, cycle II covered improvement rather in cycle I. In other words, high touch approach implementation enables students to learn better, but when it is related to learning outcomes in form of essay examination, the results are not sufficient. They still have difficulty to do reasoning or to give operational and contextual examples. They may have lack preparation to follow examination such as not used to have autonomous learning or lack of reading outside the class. 


\section{CONCLUSION AND RECOMMENDATION}

Regarding to the findings of the research, it is concluded that the high touch approach implemented by teacher through affection, mildness, guidance, directive actions, and good modeling influenced students' attitude in learning. The lecturer allows students to develop their creativity in independent learning skill, self-learning activities and student center, learning involved reward and punishment, respects students, and forms the class in U letter form, and gives tasks for students although the maximum achievement is not yet gained.

Based on the findings, the writer expects that the lecturer varies the learning through high touch approach. Although this research cannot be generalized, if the case and phenomenon is quiet the same, the approach may help lecturer during teaching learning process.

For policy makers, they need to complete learning medium and facilities to enable lecturers to improve their potentials. For the next researcher, further research is needed to improve learning process quality in order to help students to gain better learning outcomes.

\section{REFERENCES}

Anderson, T. (2004). Towards a theory of online learning. Theory and practice of online learning, 2, 109-119.

Arikunto, S. (2002). Prosedur suatu penelitian: Pendekatan praktek. edisi revisi kelima. Jakarta: Rineka Cipta.

Black, P., Harrison, C., Lee, C., Marshall, B., \& Wiliam, D. (2004). Working inside the black box: Assessment for learning in the classroom. Phi Delta Kappan, 86(1), 821.
Gainor, S. J., Goins, R. T., \& Miller, L. A. (2004). Using online modules in a multimodality teaching system: A high-touch, high-tech approach to geriatric education. Gerontology \& Geriatrics Education, 24(4), 45-59.

Gay, L. R., \& Airasian, P. (2000). Educational research: Competencies for. Analysis and Application,(6th Edition). Ohio: Prentice Hall.

Gould, J. M. (2009). Understanding organizations as learning systems. Strategic Learning in a Knowledge Economy, 119-140.

Hord, S. M. (2009). Professional learning communities. Journal of Staff Development, 30(1), 40-43.

Kriz, W. C. (2003). Creating effective learning environments and learning organizations through gaming simulation design. Simulation \& Gaming, 34(4), 495-511.

Kulchitsky, J. D. (2008). High-tech versus high-touch education: Perceptions of risk in distance learning. International Journal of Educational Management, 22(2), 151-167.

Light, G., Calkins, S., \& Cox, R. (2009). Learning and teaching in higher education: The reflective professional. Sage.

Loughran, J. (2013). Developing a pedagogy of teacher education: Understanding teaching \& learning about teaching. Routledge.

Moore, M. G., \& Kearsley, G. (2011). Distance education: A systems view of online learning. Cengage Learning.

Nightingale, P., \& O’Neil, M. (2012). Achieving quality learning in higher education. Routledge. 
Noddings, N. (2013). Caring: A relational approach to ethics and moral education. Univ of California Press.

Sims, R., Dobbs, G., \& Hand, T. (2002). Enhancing quality in online learning: Scaffolding planning and design through proactive evaluation. Distance Education, 23(2), 135-148.
Vescio, V., Ross, D., \& Adams, A. (2008). A review of research on the impact of professional learning communities on teaching practice and student learning. Teaching and Teacher Education, 24(1), 80-91. 